\title{
Vaiksed kohad
}

\author{
Mari-Ann Remmel \\ Eesti Kirjandusmuuseumi Eesti Rahvaluule Arhiivi teadur \\ mariann@folklore.ee
}

Teesid: Artikkel põhineb materjalidel, mis on kogutud kohapärimuslike objektide, sh looduslike pühapaikade kaardistamisele keskenduvatel välitöödel, ning autori isiklikel kogemustel. Fookuses on nn vaiksed kohad - nende all mõeldakse paiku, mille kohta on arhiivis vähe pärimusandmeid, ning ka kohti, mida uurijal on raske tänapäevasel maastikul ilma kohaliku teejuhita identifitseerida. Vanemate pärimuslugude üleskirjutamisest on möödunud ligi poolteist sajandit. Selle perioodi vältel on toimunud ulatuslikke maastiku ümberkorraldusi, mis on toonud kaasa muutusi inimeste elulaadis, kohalugude mäletamises ning pärimuspaikade välisilmes, vahel ka nende nimedes. Näiteks Põhja- ja Lääne-Eesti hiiepärimuse puhul on täheldatav fragmentaarsus ja kiire taandumine nõukogude võimu ajal ning varem. Välitöödel lähteülesannet täita püüdev uurija võib sattuda üpris metsikutesse või siis rasketehnikaga jõuliselt üle kirjutatud paikadesse, mistõttu romantikahõng, mis vanema pühapaigapärimuse lugemisel üles kipub kerkima, võib reaalsuses kiiresti hajuda.

Artiklis rõhutatakse, et tähenduslikud kohad kõnelevad eelkõige inimeste kaudu - peaaegu igas piirkonnas on olnud omad missioonitundelised võtmeisikud, tänu kellele meil on üldse olemas arhiiviandmed. Autor toob välja tänapäevaste välitööde probleemid, nt raskused teadliku teejuhi leidmisel, kuna järjepidev pärimuslik info koos selle kandjatega on ajaloolise objekti lähedusest sageli eemaldunud ning seda tuleb otsida mujalt. Pole harvad juhud, kus ühendust loo ja paiga vahel enam sõlmida ei õnnestu - kas on objekt hävinud, lähteandmed liiga napid või puudub ühendav lüli ehk infot valdav inimene. Kivi, küngas või allikas jääbki vaikselt oma olemisse, kuni tulevad uued inimesed uusi seoseid looma. Samas on arhiivipärimust ja vanu kaarte (asja)tundlikult tõlgendades võimalik vaikseks jäänud kohad mõnikord taas kõnekaks muuta. Kas seda kõnet aga tänapäeva inimesed enam mõistavad? Igal juhul võivad välitööde tulemused huvi pakkuda nii giididele kui ka kohaliku identiteedi ülesehitajatele.

Märksõnad: asustus, kohapärimus, looduslikud pühapaigad, maastik, välitööd

Viimasel kümnendil on Eesti Rahvaluule Arhiivi (ERA) kohapärimuse töörühma osalusel toimunud Eesti eri nurkades suuremahulisi kohapärimuse-alaseid välitöid. Looduses käies ja kohalikke inimesi küsitledes tekib mitmesuguseid tähelepanekuid nii maastiku, inimeste kui ka pärimuse osas. Uurijana tahaks kogetut avaramalt mõtestada. Mall Hiiemäe on tõdenud, et "lähenedes kohapärimusele arhiiviseinte vahelt väljumata, jääks folkloristil maastikuobjektide tegelik osakaal tänapäeva eestlase identiteeditajus selgitamata" (Hiiemäe 
2007: 232). Välitööd annavad mõtteainet teinekord aastateks. Kui tavaliselt räägitakse sellest, mida ekspeditsioonidel kuuldakse-nähakse-leitakse, siis vahelduseks on asjakohane vaadata ka teist poolt - seda, mida pole (ehkki on otsitud). Eitav teade on samuti informatsioon ning praegusel ajal mitmes eluvaldkonnas aktsepteeritud info jagamise viis (kui mõelda näiteks toidu- või kosmeetikapakenditele, millel on sageli kirjas ka ained, mida sisus ei leidu). Järelikult on ka puuduv osa uuritavast materjali dünaamikast parema pildi saamisel siiski oluline.

Siinses artiklis arutlen konkreetsete kohapärimuslike näidete põhjal selle üle, miks väliuuringutel otsitavat ei leitud ja miks peaks üldse otsima seda, mille leidmise võimalus uurijal kasutada oleva arsenali abil on väga väike. Vaiksete kohtadena käsitlen selliseid paiku, mille kohta on arhiivis vähe pärimusandmeid - sageli vaid toponüüm -, ning ka niisuguseid, mida on raske tänapäeval ilma kohaliku teejuhita identifitseerida. Paratamatult tuleb juttu muutustest nii maastikul kui ka inimmälus. Kultuurigeograaf Hannes Palangu (2014: 496) sõnul saame Eesti maastike puhul rääkida mitmest kihist: "Iga uus kiht üritab eelmist maastikku kustutada; mingis osas see õnnestub, mingis mitte. [---] Mingi osa maastikust on see, mis muutub iga ühiskonnamurranguga; mingi osa säilitab traditsiooni." Sama protsess toimub ka mälus - igal ajal kerkivad esile omad jõulisemad lood, mille varjus võib kustuda ja puhuti taas lõkkele lüüa ka varasem vaimne pärand.

\section{Välitööd arhiivist maastikuni}

Inspiratsiooniks on eelkõige Põhja- ja Lääne-Eestis tehtud välitööd, mille üks ühiseid eesmärke on olnud maateaduslik - ülesandeks oli pärimuspaigad kaardile kanda. Olen vastutavas rollis osalenud järgmistes kohapärimusele orienteeritud projektides:

1) Jüri kihelkonna kohapärimuse kogumine (2010-2011; 2015-2017), mille eesmärgiks oli raamatute koostamine (vt Remmel 2011, 2017).

2) Matsalu ja Vilsandi mälumaastike uuringud (2012-2015; 2015-2017) mille raames tehtud töö tulemusena saab Maa-ameti geoportaalis kohapärimuse rakenduses kaardile klikkides näha fotosid, lugeda tekste, kuulda jutte, vaadata videolõike. Kohapärimusele on nendes projektides lähenetud kõige laiemas tähenduses.

3) Ajalooliste looduslike pühapaikade inventeerimine (2015-2020) - tööde eesmärk on kaardistada arhiiviandmete põhjal teadaolevad pühapaigad, mis on seni riikliku kaitseta. Projekti aruande põhjal esitatakse kaitse 
alla võtmiseks paremini säilinud pühapaigad, ülejäänud kantakse kaardile pärandkultuuriobjektidena. Kaugemaks tulemuseks on avalik kaart. Fookus on kokkuleppeliselt üksnes ajaloolistel, 20. sajandist varasema tekkega pühapaikadel. Meie töörühmal on pühapaikade inventeerimisega tegemist olnud alates aastast 2017, mil töösse võeti Hageri, Rapla ja Jüri kihelkond Harjumaal. Järgnesid kokkupuude Iisaku ja osalt ka Vaivara kihelkonnaga Ida-Virumaal; 2019. aastal aga sai võimalikuks pühapaigateemal põhjalikum süüvimine Haljala kihelkonda LääneVirumaal ning Hanila ja Lihula kihelkonna ainesesse Läänemaal, lisaks on tulnud ekspertiiside jaoks uurida mõnd tuntumat pühakohta Eesti eri nurkades, nt Saare- ja Võrumaal ning põhjarannikul. Inventeerimise lähteülesanne on pealtnäha justkui lihtne - otsida arhiiviteadete järgi üles kohad maastikul, neid kirjeldada ja piiritleda. Vajadusel-võimalusel tuleb küsitleda ka kohalikke elanikke, kes saaksid kohtade leidmisel abistada. Sarnast tööd on kirjandusmuuseumis tehtud varem folkloristika osakonna projekti "Radar" raames, samuti ERA kohapärimuse töörühma piirkondlikke väljaandeid ette valmistades.

Kohapärimuse kesksetele väliuuringutele eelneb tavaliselt varasemate arhiiviteadete otsimine, käsikirjadest arvutisse sisestamine ja süstematiseerimine külade kaupa. Kohapärimuse töörühm on koostanud andmekataloogid, milles saab välitööl näpuga järge ajada. Iga detail on maastikule minnes oluline, seetõttu tekstikonspektidest ei piisa, infokildude sõelumiseks on vajalikud nii terviktekstid kui ka nende juurde kuuluvad metaandmed kogujate-jutustajate isikute ja päritolu kohta. Pühapaiku ümbritsevat pärimuslikku ja ka asustusloolist konteksti arvestamata võib tulemus jääda kesiseks. Niisuguse tegutsemisviisi juurutamisega on toimunud suur muutus võrreldes nappide küsitluslehtedega, mis nõukogude ajal ekspeditsioonile minejatele rahvaluulearhiivist kaasa anti.

Välitööetapid on üha enam omavahel põimunud, keeruline on piiri tõmmata pärimuspaikade otsimisele eelneva ning järgneva tegevusega, sest digiajastul on suur osa arhiivist kaasas ka võsa vahel - mobiilsidega ekraanide abil saab erinevaid kaarte ja andmekogusid vaadata ja võrrelda peaaegu kõigis Eesti nurkades, samuti saab salvestatud faile jooksvalt nimetada või eredamaid hetki käigu pealt sõprade-kolleegidega jagada. Ka Tiiu Jaago on osutanud, et välitöid ei saa selgepiiriliselt eristada materjali korrastamisest või selle kasutamisest uurimuses. Erinevates arhiivides "kaevamist" võib samuti nimetada välitööks (vt Jaago 2019: 88). Iga võimalikku infokildu ei õnnestugi esimese ringiga ka rahvaluulearhiivist üles leida, tuleb teha nn ristotsinguid, n-ö kammida registreid, kartoteeke, varasemaid sisestusi, väljaandeid jne. Kasuks tuleb tutvumine kogujate ja autorite isikute taustaga, tuleb olla allikakriitiline, märgata kirjavigu (nt nimedes on neid kõige sagedamini, kui ei ole just tegemist erinevate nimekujudega). 
Enne maastikule minekut andmeid koondades saame küllaltki tiheda infokogumi, mille põhjal tekivad inspireerivad kujutluspildid. Uurijat võib haarata omamoodi hasart - minna otsima just seda paika, millest on endale juba mingi ettekujutus loodud. Küllap teatud kohtade "vaatamisväärsustena" reklaamimise kaudu toidab sarnane fenomen ka turistide elamusjanu. Kui turistid ei pea enamasti ootustes pettuma, siis kohapärimuse uurija läheb tihti vastu tundmatusele. Teadlase ja eksperdina väljas olles peab ta suutma oma kinnismõtetest loobuda ning olema avatud ka uuele infole, milline see siis ka pole.

Võib öelda, et vanema arhiivipärimuse väärtus ühtpidi kasvab ajas, teisalt aga tuhmub ja selle kõnekus väheneb, kui ei leidu folkloristi või koduloolasest/ giidist entusiasti, kes sellele värskenduskuuri teeks ning taas käibesse lükkaks. Turismis on lugu see, mis müüb (vt McCabe \& Foster 2006). Seejuures "mitte üksnes ei kasutata (koha)pärimust, vaid turismi vahendusel seda ka kujundatakse ning võimendatakse. Elujõulisteks saavad seesugused narratiivid, mis vastavad turismis kehtivatele väärtuskriteeriumidele; viimased kujunevad omakorda nõudluse ja pakkumise jõuväljas" (Kindel 2005: 5). Tekkinud on turismiruumi mõiste, mida mõtestatakse lugude abil (Peil 2014: 401 jj). Kui sobivat lugu kohapealsest traditsioonist võtta pole, võidakse see tänapäeval ka spetsiaalselt välja mõelda, et erineva taustaga külastajatele muljet avaldada (Kindel 2005: 78-80). ${ }^{1}$ Kahtlemata on põnevaid ja samas sisukaid lugusid arhiiviski küllaga, ent nende väljaõngitsemiseks on vaja eelteadmisi ja omajagu ka õnne või intuitsiooni. Kuigi ühendus vana, arhiivis oleva pärimuse ja paiga vahel on tihti katkenud, õnnestub vahel siiski otsad kokku viia - tulemus võib kasuks olla ka giididele, kes väärtustavad pärimuse järjepidevust.

Kohati väga kasina info interpreteerimine nõuab sügavuti minekut, kannatlikku kaartide uurimist, kuid kõikvõimalikku taustmaterjali süüvimise abil saab vahel vaiksed kohad rääkima panna. Tihti on tegemist pigem detektiivitööga või orienteerumisülesandega, kus ettetulevate tõkete, umbteede ja takistuse hulk on mõnigi kord suurem kui leiurõõm.

Pärimuspaikade kaardistamise kõrval pole vähem oluline ka tänapäevaste pärimuslike teadmiste talletamine ja infot valdavate nn võtmeisikute leidmine. Olenevalt uuritavast teemast ei pruugi see osa tööst sugugi lihtsam olla.

\section{Rännakud muutunud maastikus}

Kui 1990. aastatel ja uue aastatuhande algul oli kohapärimuse uurijal rohkem tegemist pärimuse tõlgendamise ja mõtestamisega (vt ka Hiiemäe \& Remmel 2020), siis viimasel ajal on tähelepanu nõudma hakanud koht ise - maastik, looduskeskkond. Juba mõnikümmend aastat tagasi hakati rääkima keskkond- 
likust pöördest (environmental turn) humanitaarteadustes (vt uuemat ülevaadet sellest nt Stanton 2020). Nimetatud tendents on kooskõlas ühiskondlike muutustega, mis toimuvad üha kiirenevas tempos, ning ka kasvava murega elukõlbliku keskkonna säilimise pärast. Hoogustuv metsatööstus, uue raudtee ehitus ja kaevandamisplaanid on muutnud loodusega seonduvad probleemid üha teravamaks. Selle taustal paigutub ka pühapaikade inventeerimine abinõude ritta, mis peaksid kaitsma nii püsiväärtusi kui ka loodust.

Käsikirjalisest arhiivist tuttava objektiga, nt rändrahnu, allika või muu paigaga kohtumine on justkui kokkusaamine ammuse "kirjasõbraga" - tuttavaga, kes on pärit teisest ajast, kaugest minevikust. Sellised kohtumised on meeldejäävad. Isegi positiivselt lõppev teekond ei ole alati lihtne, kuid erinevad elamused ongi sellise töö loomulik osa.

Oleme ekspeditsioonidel kokku puutunud väga metsiku, puuke, karujälgi, ürgmetsa ja raskesti läbitavaid rägastikke täis maastikuga. Samuti on sihikindlad uurijad ületanud elektrikarjuseid, kraave, uudismaid, raielanke, kaevandusi ning ülesküntud külavaheteid. Mõnigi kord on kunagine lage karjamaa kasvanud tihedasse võssa, kus jalgsigi liikumine nõuab suurt pingutust. Tihti on kohas, kus otsime metsa, hoopis raiesmik, peoplatsi asemel võsa või mäe asemel karjäär. Need uurija jaoks kahtlemata vajalikud ja mõtlemapanevad kogemused annavad arhiivitekstidele hoopis teise mõõtme. See romantikahõng, mis nt pühapaigapärimuse lugemisel kohati üles kipub kerkima, võib reaalsuses kiiresti hajuda. Pahatihti tundub objekt unustatu ja mahajäetuna.

Näiteks Haljala kihelkonnast Aasperest on Hermann Länts (1867-1917) üles kirjutanud rea huvitavate detailidega teisendeid Aaspere Hiiemäe kohta, kus "Iie all" olevat ohverdatud vilja, villu ja verd. Kui ohvrit ei toodud, olevat järgnenud loomade kadu. Kingul kasvanud ilusad hiiepuud (haavad, niinepuud), mäel olnud ka kabel või lust-oone, kust trepp mõisa alla või Haljalasse minevat. Ehitise nurkadel olnud hobuse- ja härjapeade kujud. (Vt ERA II 153, 444 (16); ERA II 153, 555/7 (48); ERA II 153, 637/8 (19); ERA II 198, 117 (159); ERA II 198, 124 (180); ERA II 198, 272 (7).)

1939. aasta teade räägib mõisa ajal maha raiutud ilusatest kaskedest:

Aaspere mõisa pargi taga (11,5 km Kadrinast põhja poole) on koht, mida hü̈takse praegugi Hiiemäeks ja Hiieväljaks. Ennevanast old seal vanade eestlaste püha hiis. Seal kasvanud kõik valgekoorega suured kased. Mõisa asutamisega raiuti mets maha ja tehti põlluks, ainult mõned üksikud kased jäid kasvama. Aga põldu hü̈̈ti ja hü̈̈takse veelgi Hiieväljaks (ERA II 217, 298/9 (45) < Haljala, Aaspere v, Võipere k - Aadu Allvee, Rakvere Gümnaasiumi õpilane < Eduard Akberg, 68 a (1939)). 
Hiieväljal laiub praegu lage viljapõld, mille kõrval, metsistuva mõisapargi servas aga kõrgub endiselt Kreposti või Kripaste mägi (kohanimekaardil ka Klitsmägi), millel asunud ehitisest annab tunnistust vaid varisenud keldriauk kelgujäänustega. Seda mäge teadis suusamäena ka lähedases Võipere koolis käinud Heinz Valk. Hiiemäe nimi tema kõrvu ei olnud ulatunud. Kohanimi on G. Sandbergi teatel kohalikus kõnepruugis lühenenud Eeväljaks (EKLA, f 169, m 55:1, 169 (9)). Hiiemäel kunagi asunud lusthoone või kabel oli muinsuskaitseameti arhiivi mälestisepassi andmetel tõenäoliselt mõisaaegne "hiina tempel”, kus härrased kohvi jõid ja kaarte mängisid, samal ajal kui all keldris vange olevat piinatud. Sellegi paiga pärimuses on mitu eriaegset ladestust.

Vanades pärimusteadetes kirjeldatud kohti, mis ei ole heas korras või üldse leitavad, on viimastel aastatel külastatud piirkondades ilmselt rohkem kui nt pühapaikade inventeerimise ametkondliku metoodika järgi kõrgeima hindega hinnatavaid paiku. Mõnes kõrvalisemas kandis võib küll olla ka teisiti.

Praeguse maastiku kokkuviimine vanade lugudega on sageli tõeline väljakutse. Tänapäevasel loodusmaastikul võib kogeda drastilisi erinevusi kujutluspiltidest, mida vanem pärimus maalib, ning märgata ka uuemaid tähenduskihte. Eriti kunagisi pühapaiku taga otsides tundub, et oleme jäänud oma uuringutega ajale jalgu. Välitöödel kogetu ei anna kinnitust, et teadmised ohvrikividest, hiitest jne oleksid järjepidevalt kohapeal tänini püsinud (mõistagi on erandeid). 2019. aasta sügisel ütles üks vana mees Läänemaal Kasekülas: "Miks te selliste küsimustega kolm põlve tagasi ei tulnud? Nüüd on küla tühi, vaid paar peret vanu siin on, noored on Soomes tööl."

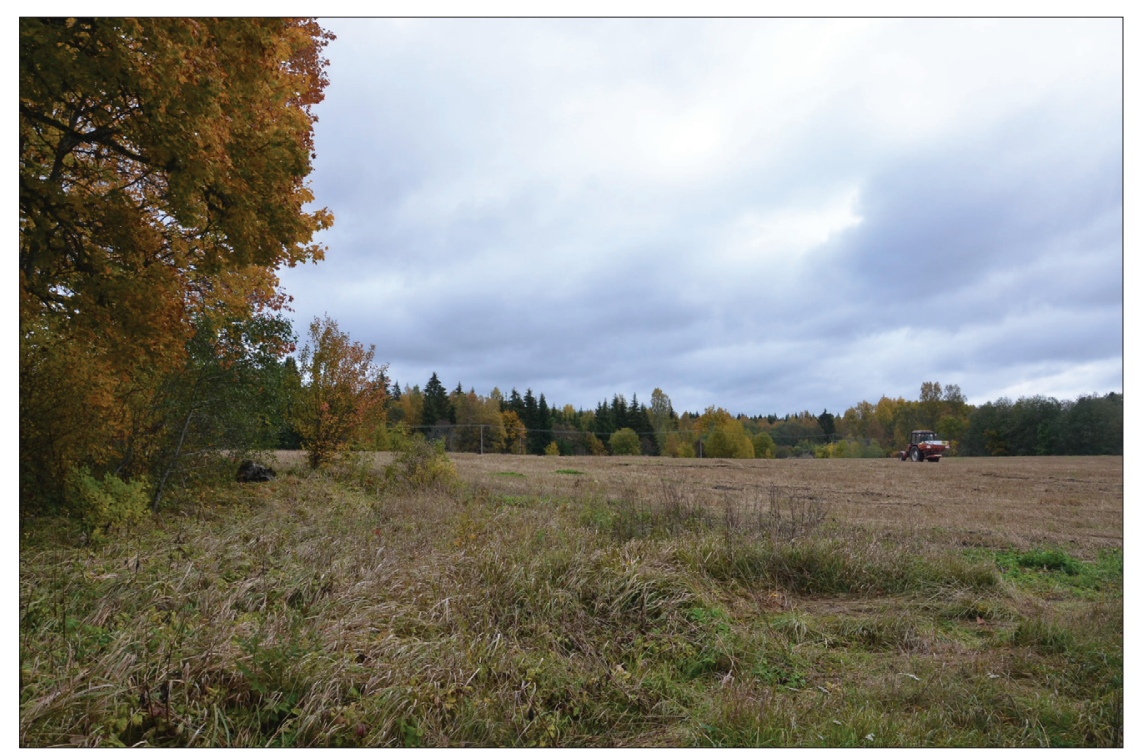

Foto 1. Aaspere Hiieväljal laiub praegu lage viljapõld. Mari-Ann Remmeli foto 2019. 
Tõepoolest, lähteandmed on sageli mitme inimpõlve tagused. Tihti pole garantiid, kas leitud kivi, allikas, mägi vm on see, millest kõneles Jakob Hurda korrespondent enam kui sada aastat tagasi, sest keegi ei kinnita oletust. Seega kas ja kuivõrd suudab uurija kõiki andmeid analüüsides seost tõestada, kui koht on "vaikseks jäänud"?

Maastikul on tunda ka varasemad n-ö ülekirjutamised ja ajaloolised murrangud, asustusmustri muutused. Neid oskab uurija märgata vaid siis, kui on olemas teadmine varem olnust, ja seda pakubki arhiivipärimus. Ent ta ei paku seda "täiskomplektina", pärimus on alati selektiivne, täpseid juhiseid ja kirjeldusi sisaldub arhiivitekstis haruharva.

Näiteks Haljala alevi territooriumil on arhiiviteadete järgi paiknenud Maheda küla hiiekoht - seal olevat olnud hiiesaun, mitte kaugel saunast väike järv (EKIKN hlj es1 ja-jo [178/82] (496399/407); EKLA, f 169, m 55:1, 169 (1); EKLA, f 169, m 55:1, 170 (1-4); EKLA, f 199, m 57, 1 18/19). Kohta hüütud "Pühad hiied" (EKRK I 4, 162/3). Haljala raamatukogus korraldatud 30 osavõtjaga teabepäeval ei olnud ükski kohaletulnud inimestest sellest hiiest midagi kuulnud ning arvatavasti uuemate eramutega täienenud hiieala oli umbkaudselt lokaliseeritav üksnes kunagiste talumaade ning praeguse Veskijärve järgi.

Haljala kihelkonnas Varangul on räägitud jõkke kukkunud ohvrikivist. Lugu on ammune, seda teatakse praegugi, kuid milline on õige kivi (veest paistis neid kolm-neli), ei oska öelda enam keegi. Tekstis nimetatud Saare talu kadunud peremeeski vist enam täpselt ei teadnud. Teave on ähmane, niisugust objekti kaitsta on raske. Ja kas see lähebki enam kohalikele eriti korda?

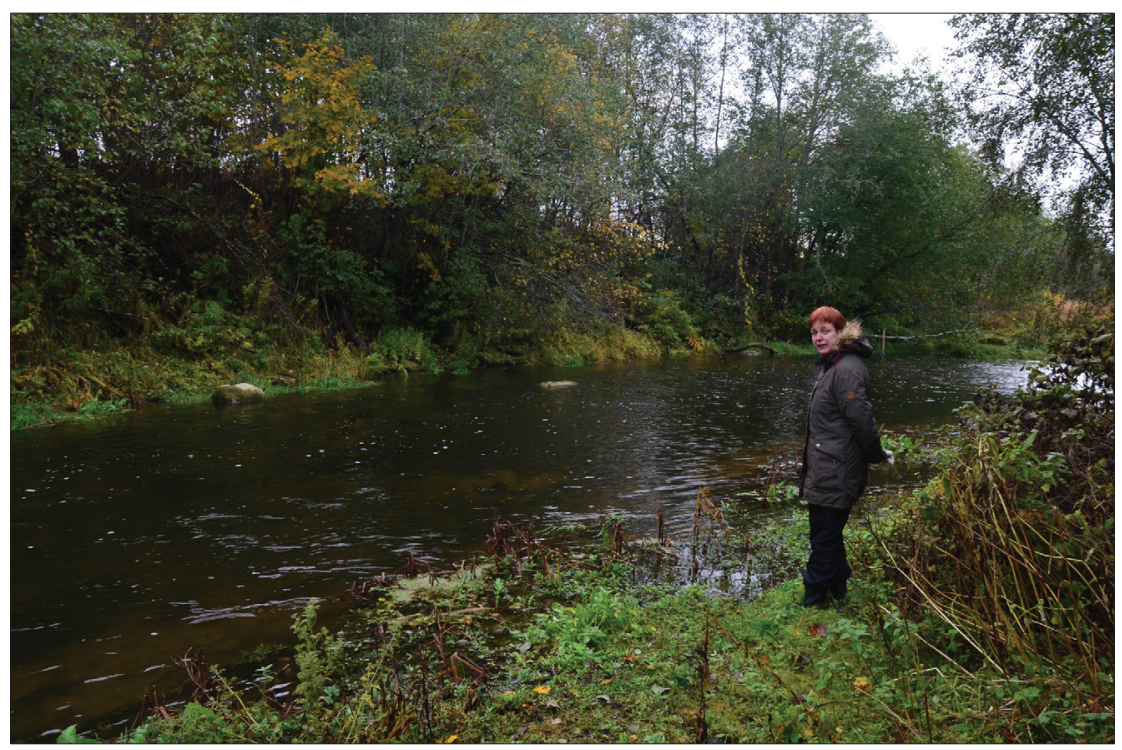

Foto 2. Varangu küla elanik Marge Salumäe näitab Varangu jõest paistvaid kive võimalik, et nende hulgas on jõkke kukkunud ohvrikivi. Mari-Ann Remmeli foto 2019. 


\section{Varangu $k$.}

Ohvrikivi oli-kukkus jõkke. Oli Saare t. vastu-jões ida pool -> Pehka. Hiiet - ei tea. Saare t. (EKIKN hlj varep2 varangu [50] (2108067)).

Oluline on teadvustada, et pole ühte ideaalminevikku, vaid asjaolud on varemgi pidevalt muutunud - ka minevikumaastik ning seda peegeldav pärimus on olemuselt dünaamiline (Bendix 1997; Kõivupuu 2014: 444). Pigem on praegu eri huvigruppide ideaalidele või ettekujutusele vastavaid mälupaiku/pühapaiku konstrueerides küsimus mälu ja seda pikendavate allikate ulatuses.

Kunagist tõelust täpselt rekonstrueerida ei saa, ehkki vanad kaardid ja fotodki annavad nii mittekohalikule kui ka kohalikule uurijale vähemalt lähema mineviku kohta vahel selgema ettekujutuse. Kui tahta aegade taha vaadata, peab täpsustama perioodi. Asustuspildis on toimunud 19. sajandilgi suuri ümbermängimisi - nt külade mõisastamine, talumaade kruntimine, hiljem mõisate jaotamine asundustaludeks jm, mille käigus sattus elamisi mõnikord otse kalmetele või hiiepaikade külje alla. Rootsiaegseid ja hilisemaid kaarte võrreldes võib tajuda, et Põhjasõja ja katku järel oli pilt varasemast erinev (Remmel 2017: 375). Pärimuses sulab kaugem minevik ühte ning kirjapandud mälestused ei ulatu aegadeni, mil on kinnistunud mõnedki praeguseni säilinud toponüümid (nt hiie- ja püha-algulised nimed). Tsaariajast varasemat maastikku võib mingil moel "näha" teiste humanitaarteaduste (arheoloogia, lingvistika, geoloogia, geograafia jm) abiga. Aastatuhandete taguste paikade tähenduste interpreteerimise osas ei saa talletatud pärimust küll tõe pähe võtta, ent vanemates kohamuistendites võib leiduda vihjeid mõnesajast aastast vanematele kujutelmadele. Seda nn kodeeritud infot pole lihtne lahti muukida ja see ei ole ka siinse artikli fookuses, sest oleme pidanud otsima vaid ca 150 aasta vältel kogutud pärimuses mainitud ja kirjeldatud kohti. Rahvaluulearhiivi andmetest teadmisi ammutava folkloristi mälu ulatub piltlikult öeldes niikaugele kui Hurda korrespondentide oma, kohalik elanik saab heal juhul aidata teabega sajanditaguse Eesti Vabariigi aja kohta, ent sooviks sageli rääkida pigem hoopis küüditamisest või kolhoosiajast...

Isegi kui mõni põline kohalik inimene otsitava objekti lähikonnas elab, ei pruugi temagi enam muutunud maastikus orienteeruda. Pärimuskoht võib olla füüsiliselt täielikult kadunud, maatasa tehtud (nt allikas maaparandusega kinni aetud). Kive on massiliselt hunnikutesse lükatud, lõhatud jne, kiviaiad on kokku veetud sadamate jm rajatiste ehitusteks. Kui karjatamist ja heinategemist pole, kasvab maa võssa. Paljud endised haritud maad on metsastunud, kunagistel rannakarjamaadel kasvavad kadakatihnikud, rannas vohab väetiste mõjul roostik, mida varem nii laialt polnud. Rahvusparkides püütakse traditsiooniliste inimmõjudega maastikutüüpe spetsiaalsete meetmetega (karjatamine, talgud) säilitada, sest see on harjumuspärane keskkond paljudele taimedele, 
lindudele, loomadele. Sellist ümbrust, mis heiastub Hurda-aegsetes tekstides või nende taga, me enam reaalsuses ei näe. Ega näe ka sellist, mis oli alles veel 1930. või ka 1950. aastatel. Vanematel inimestel jätkub ikka veel kohanemine 1960.-1970. aastate maaparanduse tagajärgedega, hoides meeles ja südames liigendatud külamiljööd, mille nostalgilist olemust võib aduda üksikutes perifeersetes paikades või rahvusparkides. Noorematele lapsepõlvest tuttav pilt pärineb juba lagedate kolhoosipõldude ajastust, mis on nüüd vähemalt pealinna lähistel kattunud moodsa aja uuselamute, ladude jm tööstusrajatistega.

2011. aastal olen oma Jüri kihelkonna kogumispäevikusse kirjutanud:

Üritasime leida allikat Mõigu mõisa juures, aga oli tegemist, et mõisa ennastki leida - vana tee, mis kaardil märgitud, oli kadunud, kruntideks välja jagatud. Uus, nn Leerimäe tee, läks mõisa juurde. See on samuti erastatud, kõikjal sildid: ERAMAA, ära tule. Läksime ikka, õues oli noorem naine, kes meie allikaküsimise peale rääkis, et enam allikate juurde ei pääse, aed on ette tehtud. Kahju. Mõisa ukse alla on kerkinud vahepeal linn - kui aastaid tagasi Raudmetsaga seal käisime, oli seal tükk tühja maad.

\section{Kust leida teejuhte?}

Olen mõelnud, et minu ja mu kolleegide sugused ringihulkujad omavad vist kõige mitmekülgsemat pilti kohalikust "lihtsate maainimeste" elust viimase paarikümne aasta vältel. Järjepidev sugulusvõrgustik ja sidemed on ju üldiselt säilinud, aga selle võrgu kandvad punktid paiknevad tihti mujal, eemal esivanemate kodust (muidugi kui inimest üldse paikse nähtusena käsitleda). Maakohtadega ja Teise maailmasõja eelsete taludega seonduvat pärimust võib ehk veel leida linnadest-alevitest, kuhu põliselanikud on olude sunnil kolinud, või lausa eksiilist. Siiski võib nüüdseks olla juba sealtki seda hilja otsida, sest taludes kasvanud vanem põlvkond on väga eakas või juba siit ilmast lahkunud. Vahepealse paari põlvkonna jooksul, nõukogude ajal, on regiooniti ka verd rohkem segatud. Mõnes külas on rohkem uusasukaid, mõnes on ka kodukanti tagasipöördunuid, mõnes pole kedagi.

Niisiis tuleb tunnistada, et paljude pärimuspaikade puhul on traditsiooniline info koos selle kandjatega sageli oma objekti lähedusest eemaldunud. Perifeersetes külades on asustus hõre - näiteks paiguti Läänemaal, kus on õnneasi, kui üldse veel inimesi leidub, tihti vaid paar-kolm peret terve küla peale. Mõnes talus elab Muhust 1920. aastail ümberasunute järglasi. Rannikualadel on palju uusasukaid, suvitajaid (suur hulk talusid on suvekodud, 
nii põliselanike pärijate kui "linnameeste" omad). Virumaal on asustus tihedam, ent side vanema pärimusega veelgi nõrgem kui Läänemaal.

"Maa sool" - ärksad taluinimesed, kellega on õnnestunud vestelda, jätavad enamasti sügava mulje oma sitkuse, koduarmastuse, tuttavlikult "eestlasliku" olekuga, mida meediakanalite kaudu edastatavates kajastustes enam eriti ei kohtagi. Nende seas leidub ka isikuid, kelle roll pärimuse kogumisel ja mõtestamisel on silmapaistvalt suur (vrd ka Jaago 2019: 89-90).

Kohtumised kohalikega veenavad ikka ja jälle, et mis tahes piirkondlikel uuringutel tuleks väärtustada ka kohalikku kogukonda ning neid kohti, kus praegu kohalikud inimesed käivad ja mis on neile olulised - vajadus loodusega suhelda on siiski teatud osal inimestest säilinud. Mõnelgi inimesel on isiklik puu, mille vastu käiakse selga toetamas ja ennast "laadimas" (siinkohal meenub ühele vanale naisele tähtis pärnapuu Järvamaal Kaaruka külas, samuti Tallinnast Läänemaale Rannakülla kolinud vana mehe suhe kodulähedaste tammedega). Virumaal Ama külas Eedumaa (< Hiietooma) talu suvituskohaks ostnud perel oli tekkinud eriline kontakt oma õuel kasvava võimsa saarega, mille okste külge riputati mingi tunde ajel krundilt leitud sarvilisi veisekolpasid. Perenaine oli saarele mõttes lubanud, et "sind me küll maha ei võta". Talu juures oli üle saja aasta tagasi kasvanud suur hiiehaab, mis Jaan Jungi (1910) väljaande ilmumise ajaks oli juba hävinud, kuid haavavõsa kasvas talu taga praegugi.

Kohad kõnelevadki eelkõige inimeste kaudu - kui kohalikku teadjat enam elus pole, siis tuleb kohaga dialoogi astumiseks panna mängu kogu muu arhiiviteave, millest sageli ei piisa.

\section{Unustatud muistendimotiivid ja hiiepärimus}

Kohalikud inimesed on (enamasti) uurijast vestluspartneri üle rõõmsad, aga teemad on võrreldes isegi paarikümne aasta taguse ajaga muutunud. Kaalukas osa vanema põlve folkloristi jaoks harjumuspäraseid, arhiivist tuttavaid kohajututeemasid on järjepidevast kohalikust traditsioonist praeguseks kadunud. Näiteks rannaaladele omaseid muistendeid kivideks muudetud pulmalistest, rändavatest järvedest, järvehaldjatest, hiidude kivikandmisest elavas esituses enam naljalt ei kuule (fragmente võib veel ette tulla). Need lood oma vanapärasuses reeglina ei kõneta enam nüüdisaegset tavakodanikku - see on ilmselt mentaliteedimuutuste paratamatu käik. Veelgi kaugemale tunduvad jäävat teated ohverdamisest, ka ravimine nt kivide juures on kadunud nõukogude ajal - või on selle koha pealt traditsiooni ja usundilise praktika elususe ajal võõraste ees suu kinni hoitud. Teisalt ei ole maal palju järel ka traditsioonilisest külakogukonnast ja taludeaegsest maakasutusest, mis eeldas mikrotoponüü- 
mide tundmist ning vajadust korduvalt mõne kivi või allika juurde asja teha. Ka visuaalne ja funktsionaalne maastikupilt on teisenenud. Hannes Palang on oma varasematele uuringutele tuginedes esile toonud, et ainuüksi 20. sajandi jooksul on Eesti maastiku loogika kolm korda pea peale pööratud (Palang 2014: 491) - pole siis ime, et ka varasema kohapärimuse lõimed katkesid. Osa teemasid - eriti mis puudutab pühapaiku ja nendega seonduvat - on pärast nõukogude-aegset suupidamise aega küll teise ringiga tagasi tulnud, ent tihti pole see järjepidev, esivanematelt kuuldule tuginev suund. Pühapaikadesse suhtumine on isikuti erinev, üldiselt on inimesed siiski neist huvitatud, küllaltki sageli võib hoiakute kujunemisel täheldada ka teemat käsitlevate trükiste (nt Kaasik 2017 jt) või meedia mõju (vrd nt Kalda 2003). Kohalike ajalehtede koduloolehekülgedel ilmus veel nõukogude ajalgi tihti nupukesi kohamuistenditega.

Ühe latiga ei saa kõiki olukordi muidugi mõõta. Eri piirkondi näinuna saan tunnistada, et kandid on mõnevõrra erinevad. Näiteks Muhu ajaloolistele looduslikele pühapaikadele keskenduvate välitööde (2005-2008) kogemus oli eriline just selletõttu, et palju uut infot saime kohalikelt elanikelt. On selge, et varasemal ajal ei tahetudki seal ohvri- ja ravipaikadest võorastele (sh Richard Viidalepale) rääkida, sest paljud neist kohtadest (nn maaljakivid) olid kasutuses veel kolhoosiajalgi. Vanad kohanimed on mõnel pool veel tuntud ja kuuldud, aga tihti on intervjueerija sattunud situatsiooni, kus tuleb arhiivitekste kohalikule elanikule ette lugeda, sest ta ei ole kuulnud isegi kirjeldatud paiga olemasolust (heal juhul teab seda mõne teise nimega).

Haljala ning ka Hanila ja Lihula kihelkonna pühapaigauuringute kogemus näitas (mõne harva erandiga), et narratiivsemad teadmised muististena arvele võtmata hiitest on kohalikust järjepidevast pärimusmälust peaaegu minema pühitud. Näiteks Lihula Peanse (Peantse) küla Hiiemetsa kohta on paar kirjalikku märget Teise maailmasõja eelsest ajast:

Hiiemets.

Vanaks eestlaste kogumise kohaks on olnud Hiiemets, liivamäed, mis asuvad Peantse küla juures maantee ääres. Enne liivamäed on suure kuuse- ja männimetsaga kaetud olnud, nü̈̈d on ta aga lage liivaväli. Hiiemets on ka pidupaigaks olnud. (ERA II 225, 337/8 (10) < Hageri khk, Kohila v, Salutaguse m - Ants Paas, Harjumaa Progümnaasiumi õpilane $<$ Jaan Paas, 58 a (1939).)

Samast Hiiemetsast ei õnnestunud hilisematel välitöödel midagi teada saada. Isegi arheoloog Mati Mandel, kes samasse külla on elama asunud, polnud sellest kohast kuulnud. Oletusi sai teha üksnes kaardi põhjal. Liivamäed sealkandis tõepoolest asuvad. Tõenäolisele paigale lähimas talus elas 2019. aastal vene 
rahvusest pere, kellele teema jäi võõraks, nagu ka kohalikule poemüüjale ning kodulooga tegelenud raamatukogutöötajale.

Veel 1970.-1980. aastail võis vähemalt Läänemaal olla märksa rohkem mäletajaid (seal on ka kaitse all rohkem kohti), Virumaa Haljala osas ei julge sedagi kindlalt väita. Haljala kihelkonnas pole seni kaitse alla võetud mitte ühtki hiiekohta ega allikat, üksnes paar kivi. Läänemaal on olukord selles osas veidi parem. Kui koht on muinsuskaitse all, toimib vana tüüpi plekist kirjaga kaitsetahvel mälupikendajana ja annab märku koha tähenduslikkusest ja väärtusest (kohalike hulgas on muuhulgas sageli käibele läinud ka arheoloogide terminid: kivikalme, kultusekivi, asulakoht jm). Tänapäevased muistist tähistavad selgitava tekstita plastpostid paraku enam seda funktsiooni ei täida. Leidub ka looduskaitsealuseid betoontähistega põlispuid või kive, mille kohta leidub arhiivis pühapaigainfot. Mõnikord on ähmaseid orientiire sisaldava teksti sidumine "parandatud" maastikul säilinud üksikobjektiga väga oletuslik ja peamiselt kõhutundel põhinev, nagu näiteks looduskaitse alla võetud Massu Suurkivi ehk Surikovi kivi puhul, mis kaardiandmete järgi paikneb mõisaaegse Vitsiku talu maade piirkonnas. Tahaks järgnevat teksti selle kiviga seostada, ent kindlus puudub - maastik on palju muutunud ja lähteandmed hämaravõitu.

Vitsiku mägi on Vitsikus, Lihulast 10 versta eemal. Seal oli väga suur ja tihe mets, kus hunt võis püssikuuli eest varju leida. Seal mäel on üks suur kivi, mida kutsuti ohvrikiviks. Seal kivi peal on ennemalt ohverdatud jumalatele ande, ja seal on veel hiie tamm kus ennem palumas käidi. See mägi on koos kividest ja kaljurahkidest. Selle on uhtunud meri ja jä̈̈liustik. (ERA II 228, 130/1 (10) < Lihula khk, Lihula v, Lihula al Elmar Hannok, Lihula alg- ja erareaalkooli õpilane < isalt, 51 a (1939).)

Vahel - üpris tihti nt hiite puhul - on ka vanem arhiivipärimus väga napp, viidates omakorda kaugemas minevikus või siis juba sajand või rohkem tagasi toimunud mentaliteedimuutustele, kommete või teadmiste hääbumisele: nt teated mõisa ajal hiiemetsa maharaiumisest või hiiemäe territooriumil kruusavõtmisest. Tihti on kirjas vaid hiie-sõna sisaldav toponüüm, millele siis on võimalus vastavalt taustteadmisele sisu juurde mõelda ning koha ülesleidmisel vaadata, kas käesolevas maastikusituatsioonis on midagi sellist, mis võiks anda meie parimatele teadmistele tuginevalt kinnitust kunagisest pühast paigast. Arheoloogia aspektist on unustatud hiite leidmise võimalikkuse üle arutlenud Tõnno Jonuks (2011). Samas pole enamasti kahtlust vastavate toponüümide eheduses, millele leidub kinnitusi ka rootsi- ja tsaariaegsetel kaartidel - näiteks ümbritsevast madalamast maast eristuv Hiiesilla ( < Hiieselja) küngas on näidatud 17. sajandi kaardil ${ }^{2}$ Haljala Karula mõisale kuulunud Igesellia welia põlluna, kus kaardipildi põhjal leidus toona nähtavasti ka kivivaresid või kive. Nüüd on see lage kultuurheinamaa. 
Alati ei ole teada isegi toponüümi, või on see vahetunud - uus kihistus on peale tulnud. Nii on juhtunud näiteks Liiguste külas, kust on juba 19. sajandi lõpul üles kirjutatud huviäratav lugu Laagrimäest. Kirjutaja sõnul olevat seal olnud aiaga ümbritsetud hiiekoht.

Iiedest ja ohvri kohdatest, pärisin ka M. Schönbachi kääst sain sellesama vastuse, mis koerakoonlastestki: kül kuulnud lapsepõlves aga äraunustanud. Ütles Aaspere mõisa maa peale Liiguste küla ligidal, hü̈̈takse ühd kõrget maad Laagri määks sääl on üks Iie koht olnud. Iie kohas peetud iga Neljapääva ôhtu Toora püha, Iie kohal olnud aed ümber, et loomad senna ei ole peasnud, see on üks püha koht olnud. Iga Neljapää õhtu on inimesed senna kokku kogunud, ja Toorapilli mängul tantsinud ja mänginud, vahel homikuni Toora auks. Sest Toora pillist on nü̈̈dne toropill saanud. Iie kohal on üks puu ehk metsa salk olnud, ja need puud on nii pühaks peetud et sealt ei ole ühdki oksa ega lehde tohtinud võtta ega murda, ja neid puid ei ole keegi tohtinud maha rajuda. Sest Toora pühast on see Neljapääv pidamine tulnud, et Neljapää õhtu ei tohi tööd teha, ja see pruuk peab praego veel mõnes kohas olema. Minu lapse põlves ei tohdinud Neljapääva õhtu muud tööd teha, kui riitid lappida. (E 19430 < Haljala khk, Metsiku - Danel Pruhl < M. Schönbach (1895).)

Laagrimäe nimi, mida on ka hiljem $(1931,1939)$ korduvalt kirja pandud, tuleneb pärimuse kohaselt Põhjasõjaaegsest Rootsi sõjaväe laagrikohast. Mäe ümber olevat olnud ühe teate järgi 1,5 m kõrgune mullavall (ERA II 222, 218 (12)) ja seal käidud Eesti iseseisvusajal jüriöö aastapäeva tähistamas (võrdlusena võib mainida, et ka Repniku Hiiemäel kasvab Jüriöö tamm).

Aaspere vallas Liiguste külas Tallinna-Narva maantee ääres (84 ja $85 \mathrm{~km}$ vahel Tallinna) on Konsu talu karjamaal lage plats, mis nüüd juba kipub lepikusse kasvama. Seal olnud Karl XII Põhjasõja ajal oma vägedega laagris, sellepärast hü̈̈takse seda kohta nüüd Laagriplatsiks. Mõned aastad tagasi, kui veel jüriööd pühitseti, korraldasid kohalikud organisatsioonid rongikäike sinna platsile, kus põletati ühiselt jüriöö tuld. (ERA II 217, 317 (62) < Haljala khk, Võipere k - Aadu Allvee, Rakvere Gümnaasiumi õpilane < August Allvee, 45 a (1939).)

Välitöödel ning kaarte vaadates oli seda kohta päris keeruline paika saada. Laagrimäe nime enam kohalikud ei mäletanud (nõukogude ajal ilmunud Veera Saare (1973: 31) raamatus "Elas kord mees..." on seda veel mainitud). Kohalik pood, mis ühe 1939. aasta koolilapse teatel asus mäe läheduses, hävis Teise maailmasõja aegu. Poe kohta teadis siiski Konsu talu praegune umbes 60aastane peremees, tema abiga suutsime Laagrimäe koha lokaliseerida. Põlluks küntud mäest on üle käinud kapitaalne maaparandus ja ühele servale on pärast 
sõda istutatud männid, aga läbi ajastute korduvalt nime vahetanud kõrgendik on maastikul siiski endiselt tunda. Sama mäge kirjeldatakse Korni mäe nime all järgnevas hiljuti talletatud tekstis:

Kui on poe juures, siis ma tean, kus see on. Mäge kutsuti viimati Korni mäeks. Mäelt leitud vanu münte. Veel nõukogude ajal oli mäel väga sügav lahtine, turvamata kaev suurte põllukividega vooderdatud. Kunagi olnud mäel veski ja maja laudaga, kus elanud õmbleja Korni Selma. Kõik ehitised ja kivid lükati buldooseriga tasaseks, mõned kivid mäe ääre pool metsariba pool näha.

Vanasti olid all oja ääres üleujutused, rohkem kevadeti. Vanaisa oli pü̈̈nud sealt hauge. Nii vesine oli, et ta isegi parvetas seal metsaservas. Nü̈̈d on oja süvendatud koppadega, tehti kraav sinnapoole, drenaažid pandi sisse. Aga tõmbas ka Konsu talu kaevu kuivaks. Memm oli ilma veeta, kaev kuiv (Mari-Ann Remmel < Urmas Kurvits, Konsu t (vahepeal elanud mujal, sh Soomes), u 60 a < sugulastelt (2019)).

\section{Võtmeisikute roll pärimuse levikul}

Pärimusinfo läbitulek ajakihtidest on justkui loterii. Paljudel juhtudel on see pudelikael väga peenike. Sageli on piirkonnas omas ajas vaid mõni üksik huviline inimene, mälu ja pärimuse kandja, teadlik mõtestaja või "kroonik", kelle hoida ja edastada on info möödunu kohta (nt Hermann Länts, Harald Kadari, Gustav Sandberg Haljalas, Helmut Polberg Virtsu kandis) - seda ka teistelt kogudes ja kirja pannes. Tihti on tegemist tundlikumat sorti, kunstimeelega ja tugeva missioonitundega inimestega. Heaks näiteks on siin Heinz Valk, kelle üleskirjutustes kajastuvad isiklikud kontaktid nii Viru- kui Läänemaaga. Sedalaadi vastutust ja huvi tunnevad ka vastava eriala töötajad, nt pärandkultuuri spetsialistid rahvusparkides.

Mitmes piirkonnas on olnud ajal, mil kohalikud veel vanemat pärimust teadsid, omad entusiastid, kes on kirjeldanud hulka muistiseid, sh ka pühapaiku. Paikadest teavitamine ja kaitse alla võtmise korraldamine on uuemal ajal olnud arheoloogide pärusmaaks. Suuri teeneid on Läänemaa osas Mati Mandelil ja ka Vello Lõugasel, seevastu nt Haljalas pole sellist eestkostjat ilmselt õigel ajal leidunud ning uurimused on jäänud kaustadesse - nii on kodu-uurija Harald Kadari külauurimuses ${ }^{3}$ kirjeldatud Pühaallikad selle artikli kirjutamise ajal veel kaitse alla võtmata, ehkki tegemist on looduslikult silmapaistva ja omal ajal tuntud ohvripaigaga. Allikate lähistele rajati nõukogude ajal prügihoidla. 
Haljalas on asendamatud tsaariaegse kohaliku teadushuvilise kooliõpetaja Hermann Läntsu (1867-1917) ülestähendused - teda huvitasid nii pühapaigateema kui ka muud muinasväärtused, samuti maastiku geomorfoloogilised aspektid. Kindlasti mitte tüüpiline rahvaluulekoguja Länts on kirja pannud mõnedki detailsemad hiie-tekstid, milles on tunda nii teaduslikku püüet kui ka ajastuomast rahvusromantilist mõtteviisi. Tema küllaltki raskesti dešifreeritavates kirjutistes heiastub 19. sajandi maastik koos omaaegsete koha- ja talunimedega, mis esinevad ka vanadel mõisakaartidel - need kaardid muutuvad tänu sama ajastu pärimusele hoopis kõnekamaks.

Kolhoosiajal, kui traditsiooniline külamaastik sattus hävimisohtu ja mõnel pool kadusid terved talude rühmad koos lähiümbrusega, oli ohvrikivide ja muude selliste kolhoosiideoloogia seisukohast iganenud nähtuste säilimine õnneasi. Kui leidus keegi, kes suutis masinamehi ümber veenda, siis jäi puu või kivi alles. Uus põlvkond neid varasemate keeruliste aegade piiripealseid olukordi enamasti ei tea, kui neist just vahetult paiga juures infotahvlil juttu pole. Sellest vaikib paraku tavaliselt ka arhiiv, sest kui niisugust infot siin-seal jutusabas kirjas ongi, pole see arhiivisüsteemis eraldi märgendatud. Järgnev näide kajastab kohaliku peremehe entusiasmi ohvrikivi päästmisel:

Ohvrikivi Kelu k. Säära-Jaani talu juures on seni paigal püsinud tänu talu peremehe entusiasmile, sest juba kaks korda olevat traktor seal juures olnud, et kivi vedama hakata. Kivil on vähemalt 7 väikest auku.

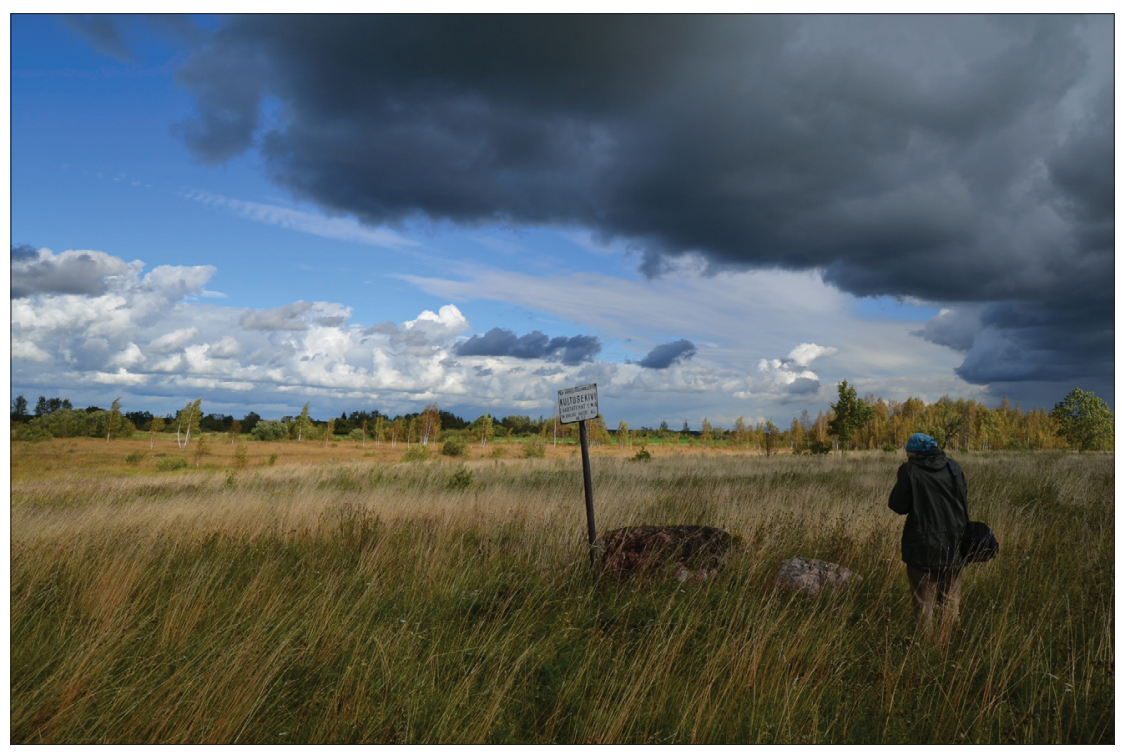

Foto 3. Kaitsealust Säära-Jaani ohvrikivi pildistab Pille Vahtmäe. Mari-Ann Remmeli foto 2012. 
Kivi juures oli viimane ohverdamine siis, kui sm. Viidalepp seal käis ja pildistas. Hiljem ei olevat enam mingeid ohverdajaid nähtud (RKM II 254, 36/7 (21) < Kirbla khk, Kelu k - Ellen Liiv (1968)).

Jüri kihelkonnal vedas seetõttu, et seal tegutses väsimatult harrastusarheoloog Oskar Raudmets, kes külastas 1960-1970. aastail paljusid kohalikke peresid, tegi asjalikke ülestähendusi ning suhtles ka Tallinna arheoloogidega, mobiliseerides neid muistiseid kaitse alla võtma. Ta aitas paigaldada ka tahvleid arvukate kivide jm kohtade juurde. Oskar Raudmetsa südameasjaks oli ka rahva harimine arvukate ajakirja- ja ajaleheartiklite kaudu ning temast räägitakse ümbruskonnas seniajani. Siit nähtub taas, kui oluline on mõnikord olnud ühe isiku panus koha säilimisel ja ka pärimuse vahendamisel.

\section{Suguvõsasisesed infokanalid}

Olen kodukandi pärimust uurides märganud, et lood on levinud nii ajas kui ruumis sugulusniite mööda. Oma kogemusest võin öelda, et tean oma suguvõsa pärimuslugusid tänu sellele, et külas, kus on mu isakodu, oli säilinud kohalik sugulussuhetel põhinev järjepidevus. Teadlik pärimuse edasiandmine toimus põhiliselt ühe ligi saja-aastaseks elanud sugulase (tsaariaegsest kooliõpetajast vanatädi) poolt. Ta käis linnast bussiga tihtilugu maal, oma sünnikodus, ning jõudis pereringis valgustada nii minu isa kui ka minu põlvkonda. Kaugemate külade sugulasi küsitlesin juba ise teadlikuma, folkloristiks õppinud täiskasvanuna.

Teisalt olen jällegi mõnel pool tähele pannud, et kui eraldi ei küsi, hoiab vanem põlvkond oma teadmised endale, kartes, et lastel pole kasulik liiga palju teada, ja püüdes takistada oma põlvkonna tundlikku infot edasi kandumast. Mõned informandid on tunnistanud, et on lugusid või kombetalitusi salaja pealt kuulnud ja kõrva taha pannud.

Vanavanemate võimalused noorematele pärimusinfot jagada on nüüd mitmel põhjusel ahenenud, samas on ka varasemal ajal oma pere lapsi vahel koheldud kui "võõraid", kelle kuuldes kõike ei räägitud. Minu üks vanavanema, kes kolis 1930. aastatel Valkla rannast koos perega ümber sise-Harjumaale, tavatses öelda: "Roostetanud puss on seinas". See oli parool juhuks, kui seltskonnas oli keegi, kelle kuuldes ei tohtinud ühest või teisest asjast rääkida. Kui see keegi oli laps, siis öeldi pussi asemel nael. Ühtegi Kuusalu kihelkonna kohajuttu nendega järeltulijatele edasiandmiseks Harju-Jaani kaasa ei tulnud, ju ei taibanud lapsed ka küsida, sest seda polnud tarvis.

Tänapäeva lapsed ei ela sageli enam vanavanematega koos, käivad koolis linnades, pärimuse vahendamise situatsioone (nt suguvõsa kokkutulekud vm) 
on harva. Sügavam side kohaga, selle olemuse tajumine ja lugude omaksvõtt tekib aga pigem korduval kokkupuutel ja vahetu suhtluse käigus, milleks nutipõlvkonnal on ilmselt valmidust vähem.

Niisiis: ühelt poolt oli nõukogude ajal fookus töötegemisel ning polnud aega või tahtmistki rääkida, teisalt ei julgetud või ei peetud sobivaks kõike rääkida. Kui juhtum puudutas valgustkartvaid pereliikmetega seotud tegusid, hoiti pigem suu kinni. Küllap oli see nii ka vanadel segastel aegadel, kui sõdade ajal ja järel liikus röövleid, kes vaikselt maha notiti, "varandus" omastati ja laip talu lähistele kivi alla maeti. Nii on öelnud Nabalast pärit teadjanaine Mai-Agate Väljataga, et "rääkima hakkasid alles lapselapsed”. Tema lapsepõlvekodus, ühe suguvõsa poolt asustatud metsataguste hajatalude rühmas, millest hiljem sai Metsanurga küla, teatakse siiani legendi röövli tapnud esivanemast - taluperenaisest või teise variandi järgi mehest.

Traguni kivi - see asub Eesmäe (kõrgendikul kasvav kuusik, mis hävis täielikult 1967. a. augusti tormis) lääneservas ja nime on ta saanud tapetud traguni matmispaigana. Põhjasõja aegu. Need olid Karl XII eliitväeosade võitlejad, nende pikkus kü̈̈ndis 2 meetrini. Neil oli kombeks teha küladesse röövretki toiduhankimise ja naistevägistamise eesmärkidel. Külaelanikud hakkasid vastu ja vastuhakk lõppes enamikel kordadel ühe poole surmaga. Metsanurga külas on traguneid otsa saanud 3. Keegi ei pidanud selle üle arvet ja hoiti salajas, rääkima hakkasid alles vastuhakkajate lapselapsed. Siis on ka raske vahet teha - kus tõde, kus vale. Aga legendile tragunite käitumisest ja tapmistest pani see alguse.

Kaks tragunit on maetud Vana-Metsari rehetoa põranda alla. Lugu ise liikus nii: Vana-Metsari vana-vana perenaine olevat üksi heinaajal kodus olnud ja heinal olevale perele süüa vaaritanud, kui tulid ratsahobustel 2 tragunit ja nõudsid oma. Metsari vana-vana-perenaine olevat olnud tugeva kondiga maatõugu naine, kellel oli suur ja kopsakas keha. Naljahambad ilkusid tema paksuse üle ja see paksus olevat olnud nii suur, et nädala sees läks lauanuga kaduma. Perenaine leidis noa üles laupäeval saunas oma kõhuvoldi vahelt.

Perenaine meelitas mehed ükshaaval rehealla ja tappis nad heinahanguga, hobused lasi aga lahti ja kihutas tuldud teed tagasi. (EFA I 210, 25 (2) < Tallinn < Jüri khk (2013), vt ka Remmel 2017: 306, 318.)

Praegu ei osata enam kindlat Tragunikivi näidata, ka põliskohalikel - nii vähe kui neid kohapeal veel leidub - on vaid oletused. Kas Metsanurga elaniku Elmar Metsari "võileivasöömise kivi” võib olla Tragunikivi? Metsari talu hävis kolhoosiajal, varemed lükati hunnikusse ja pärijad seadsid end sisse mujal. Kui eakale Metsari peretütrele kivi fotot näitasin, vangutas too kahtlevalt pead. 


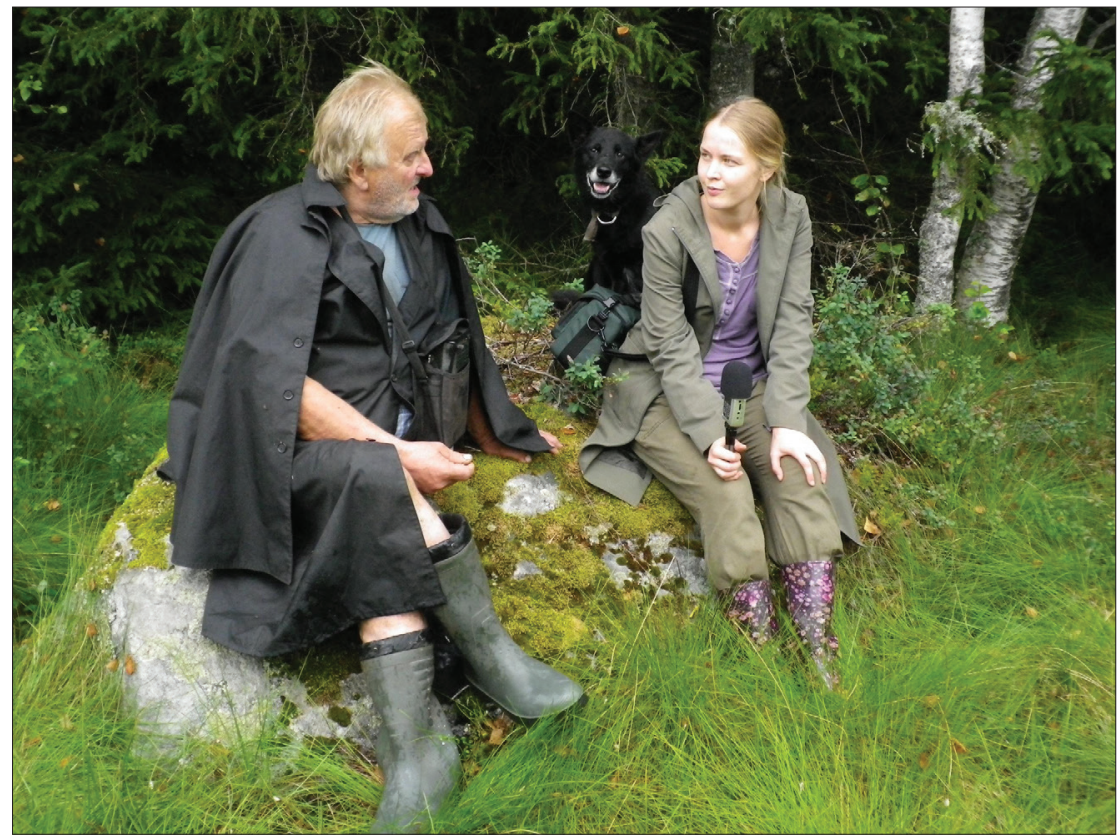

Foto 4. Metsanurga küla. Elmar Metsar (vasakul) istub folklorist Pille Vahtmäega kivil. Kas see Elmari "võileiva söömise kivi" võiks olla pärimusjuttudest kuuldud Tragunikivi, pole kaugeltki kindel. Mari-Ann Remmeli foto 2010.

\section{Pühapaikade otsimise ja leidmise lood}

Nõukogude aeg, kolhoosiaeg ja küüditamine on teinud suure laastamistöö, asustust ja maastikkugi on rohkelt segi paisatud. Siiski leidub ka Siberist, Soomest või linnadest naasnuid, sitkeid järjepidevuse järgijaid. Ranna-alade külades avaldab senini suurt mõju asjaolu, et väga paljud põgenesid üle mere Rootsi, nende seast tagasitulijaid on väga vähe. Talud jäid tühjaks, nüüd on suur osakaal suvitajatel. Stereotüüp paiksest eestlasest peab üha vähemal määral paika. Sidemed nn juurkodudega siiski veel kestavad ning need on kohati üsna tugevad. Eestlasest on saanud maa ja linna vahel pendeldaja, nagu ka Valdur Mikita (2013: 146) on esile toonud. Eks rännatud on varemgi, aga küsimus on amplituudis ja sageduses. Uute tulijate ja suvitajate kiindumus maasse, maakodusse paneb huvi tundma ka kohapärimuse vastu - tahetakse teada, kes on enne seal elanud ja millised on nn mälupaigad. Nii võib juurtest eemaldunud, kuid kunagist kodupaika külastava põliselaniku ja uusasuka kohtumisel toimuda oluline episood - pärimuse edasiandmine ning salvestumine uute elanike mällu. Oleme välitöödel mõne konkreetse paiga puhul mõnigi kord jälile saanud just sellistele skeemidele, mida hiljem üks asjaosaline siis uurijale vahendab. Kui aga see info edastamise akt jääb toimumata, siis jääbki koht vaikseks või hakkab kunagi rääkima "teist keelt". 
Piisab tõepoolest ühest teadjast inimesest, kelle kaudu info edasi liigub, ent vajalik on ka vastuvõtja pool. Siin ongi ka küsitlejatel-uurijatel oma roll, et infot n-ö käibes hoida, seda väärtustades ja pinnale tõstes. Võib arvata, et juba varasemal ajal esines nn kriitilisi situatsioone, kus võimalust pärimuse edastamiseks oli vähe - nt pärast suuri sõdasid ja katke, ajaloolisi murranguid. Praegu kogeme tagajärgi, mille tõid nõukogude aeg, kolhoosikord ja küüditamised.

Eredalt jäi 2018. aasta välitöödelt meelde Vaivara kihelkonnas Perjatsi külas kohtumine ligi 90aastase Meedy Hiieloga, kel ühena vähestest Ida-Virumaa elanikest on õnnestunud elada järjepidevalt oma isakodus. Temaga vesteldes tuli pähe küsida ka Repniku (praegu Hiiemetsa küla) hiiemäe kohta, mis jääb Perjatsist veidi eemale. Saime teada, et Meedy oli oma perest ainsana ellu jäänud (vanemad ja õde tapeti), töötanud metsnikuna ja juhendanud puude istutamist ümbruskonnas - sõjaajal hävisid isegi selle kandi puud ja metsad. Kord Repniku Hiiemäe kandis 1970. aastal kuuski istutades oli ta võsas sõna otseses mõttes komistanud suure kivi otsa, milles arvas ära tundvat Hiiekivi või Liukivi. Sellest kivist oli talle varem samas külas rääkinud üks vana mees, kes oli juhuslikult just samal päeval kodukanti käima sattunud, kui Meedy seal tööl oli. Kuuldud pärimus oli väga arhailine. Kui poleks olnud seda kohtumist, poleks ei meie ega ka keegi teine taibanud seda kivi küllaltki suurel ja osalt kruusavõtmisega segamini songitud hiiealal otsida. Hiljem on Meedy seal mõnede huvilistega veel käinud, võttes kivi jaoks ka ohvriande kaasa. Infot selle kivi kohta hoidis Meedy ühe kohaliku kodu-uurija soovitusel aastaid saladuses, sest avalikustamine oleks ohtu seadnud Hiiemäe ääres teekaldal seisva Kanepkaula kivi, mida sooviti kaitsta. Ju siis oli kogukonnas arvamus, et hiies võib olla vaid üks tähtis kivi, tegelikult on see piirkond aga suurte kivide poolest rikas ja lood võivad seostuda mitmega, samuti muutuvad aja jooksul kivide tähendused - pinnale võib tõusta mingi aktuaalsem motiiv. Järgnevalt on toodud Meedy meenutus seoses Hiiemäe erinevate pärimuskihtidega:

Hiiemägi veeti ära Tallinn-Narva maantee parandamiseks - see oli üle 10 m kõrge. Laagna mõisa poolne ots jäi kõrgemalt alles. Sinna oli ette nähtud istutada mets peale. Istutasime seal, kui siis tuli üks vana papi Hiiemetsa teed mööda. Tema siis rääkis: "See oli Hiiemäe... Liukivil oli oma Liukivi haldjas või hoidja, ja teine kivi on tee ääres, vanapapi jutu järgi on ta kogu aeg Vargakivi, selle kivi taga valvasid Hiiemetsa talunikud, keda röövida - kui kruus veeti ära, kivi veeres alla tee äärde. Reebniku küla papi oli, perekonnanimi oli Vodja. [---] Hiiemäe lõunapoolsel küljel ja Liukivi juures pidi elama Hiievana, see olevat soodustanud külarahva elu. Sinna käidi andeid viimas ja palumas. Paremat kätt on ka suur kivi (teine) maa sees, see on saanud pommitabamuse, kivi on kiirtega praguline. Selle kivi peal siis istusime ja vaatasime ja paitasime kivi, - et sõda ei jätnud ka kivi rahule. - Küsisin tookord sellelt papilt, kui 
vana ta on. Ta ütles, et "mina olen juba nii palju üle 80, et neid aastaid enam ei räägita”. Kepiga läks, ühte külge pidi. Tal oli taskus vanaaegne uur, võttis siis selle uuri ja vaatas - oi, minu buss on tulemas! Ja rohkem me ei saanudki rääkida. [---] Hiiemetsa tee asemel on nü̈̈d Torpani tee. Kivid, mis tulid kruusavõtmisega välja hiiemäest, jäid kõik maha (suured kivid, mis seal praegugi). Hiievanale viidi rätikusse mähitud uudseleiba, see pandi kivi peale. Seda rääkis see vanamees. (Mari-Ann Remmel, Mart Hiob < Meedy Hiielo, Vaivara khk, Perjatsi k (2018).)

2020. aasta alguses rääkis Lihula aleviserva 1960. aastatel Vellaverest kolinud üle 80aastane naine põnevaid seiku tema kodu lähedal hiiealal asuva ohvrikivi, nn Neitsikivi kohta, näidates kätte ka kivi asupaiga. Seda naist (ega ka arhiiviandmetes mainimata kivi) ei oleks ma osanud kindlasti otsida ilma Lihulas suvekodu omava tuttava abita, kes oli memmega juba kunagi aastate eest juhusliku bussivestluse käigus kivist kuulnud. Kuna vanamemm ei olnud kohalik, tundsin huvi, kuidas ta sellist asja teab. Selgus, et tema infoallikas oli temast veidi vanem Lihula päritoluga naine, kes oli mujale abiellunud, aga käis vahel Lihulas.

Küllaltki varjatud info levikukanalite hargnemiskohti ei onnnestu uurijal kaugeltki iga kord kindlaks teha, jälgi ajades võib sattuda eksiteele. Haljala kihelkonnast on Eesti Keele Instituudi murdekoguja Helmi Vint 1940. aastal kirja pannud lakoonilise teate, et Suurekivi e Saare talu koplis on Ukukivi. ${ }^{4}$ Külanime pole sedelil märgitud, ühe teise teate toel oletasin, et kivi võiks olla ühes rannaäärses külas. Sealse Suurekivi talu maal seisab praegu ilus eestiaegne, korrastatud elumaja, mille lähedal võib näha mitu suurt kivi. Välitööpäeval polnud kedagi kodus, seetõttu jätsin ukse vahele kirja: "Hea pererahvas, äkki olete midagi kuulnud Ukukivist oma talu maal?" Pärast sain ühe kohaliku pere abiga teada, et talu endised omanikud põgenesid 1944. aastal Rootsi, hiljem on käinud majapidamine käest kätte ning nüüd on uutel hoolivatel omanikel seal suvekodu. Varsti tuligi kõne perenaiselt, kelle jutust selgus, et nende peres on omad lood kividega, mille taga peituvat aegajalt lihavõttejänesed jne. Neil olevat kohe olnud eriline tunne selle kohaga ja nende kividega ning valmidus vastu võtta pärimuslikku teadmist Ukukivist oli suur. Kahjuks ei saanud ma anda talle vettpidavat kinnitust, et otsitav Ukukivi asub just nende talu maal. Hiljem arhiiviandmetesse süvenedes tekkisid pigem kahtlused. Ka Haljala kihelkonna mitmes teises külas on Suurekivi talud - see nimi pole kivisel põhjarannikul haruldane. Kaardid, mille lehenumbritele Eesti Keele Instituudi kohanimekartoteegi teated viitavad ning kuhu ilmselt objekti asukoht oli märgitud, on aga sõjakeerises hävinud. Ehk seostus see Ukukivi nimi hoopis Katela küla hiiekiviga, millest 1992. aastal Eduard Leppiku väitel ${ }^{5}$ kohalikud midagi ei teadnud ja mida ka meie ei leidnud. Niisugust detektiivitööd tuleb 
vanu pühapaiku otsides teha tihti, ja nii võid leida küll palju huvitavat, ent mitte tingimata seda, mida otsid.

Mõned kohad, mis kaua aega on vaiksena püsinud, on siiski rääkima hakanud. Nii läks näiteks Vihula hiiega, mille asukohta kaua aega ei teatud. Arhiivis on üks 1875. aastast pärit ilmekas tekst, mille kunagi saatsin ka Igor Tõnuristile, kes Vihulas Viru Säru korraldas. See on Toomas Lepp-Viikmanni autobiograafiline ülestunnistus, kuidas ta pistis nahka Iieniidi lähistelt sipelgapesast leitud ohvriks toodud kanamunad, ilma et midagi halba oleks sellest juhtunud (E 8487/9). Kus see Iieniit aga asus, oli ka kohalikel pikka aega teadmata. Võtmeisikuks kujunes kohaliku päritoluga kultuuritegelane, kes oli seda toponüümi kuulnud juhusliku vestluse käigus oma eakalt sugulaselt. Nii siis taasavastati see koht alles 2006. aastal Viru Säru käigus rahvusromantilise juurteotsimise tuultes, ning senini leidub inimesi, kes Iieniidi kõrval asuvat pärnasalu aeg-ajalt külastavad. Uurijatele andis siin otsa kätte internet, kus oli avaldatud hiie leidmise lugu. ${ }^{6}$

On ka kohti, mis on vaiksed üksnes arhiivimaterjalile tuginevate uurijate jaoks ning hästi teada kohalikele, kes seal aktiivselt käivad - need on praeguse aja looduslikud pühapaigad. Näiteks Koljaku allika kohta ei leidunud ERAs ühtki teadet, ent rahvas teab, et allikavesi on tervendav ja kosutav ning Võsu rahvas pidavat puha sealt vett tooma. Samas, üht vana ja raskesti lokaliseeritavat arhiiviteksti võiks ehk selle allika piirkonnaga hea tahtmise korral ka siduda:

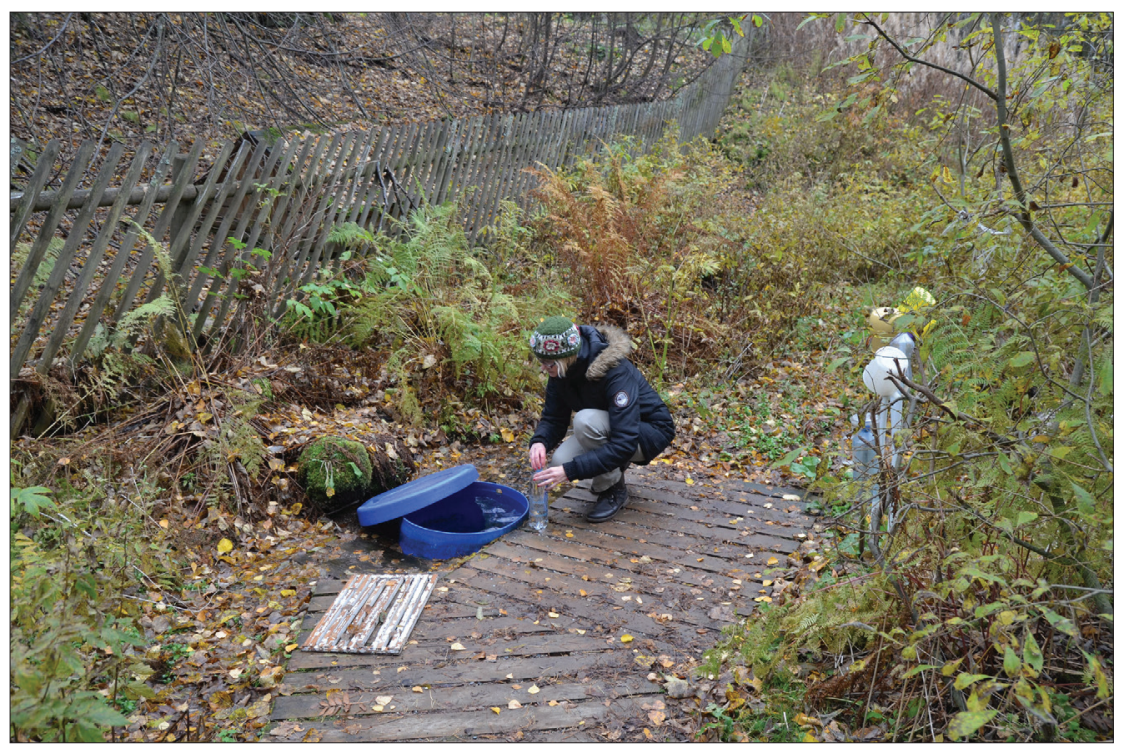

Foto 5. Koljaku allikast rahvaluulearhiivi teated vaikivad, ent kohalik rahvas teab, et allikavesi kosutab. Kiidetud nestet ammutas endale keelekasteks ka folklorist Inge Annom. Mari-Ann Remmeli foto 2019. 
Palmsi mõisast 5 versta mere poole on üks mets, mis hü̈̈takse Iie aluse mets, sääl on ka üks mää seljandik, hü̈̈takse Iie aluse seljandikuks. ((E 8) E 6789 (3) < Haljala, Metsiku - Danel Pruhl (1889).)

Kohapärimust leidub arhiivis paraku ebaühtlaselt - nt suuremad ekspeditsioonid on muutnud mõnedki kohad arhiivi kontekstis eriti "häälekaks", sest tihti on küsitud seda, mida juba eelnevalt teatakse ning seda on samal ajal päritud paljudelt inimestelt. Näiteks Lihula kihelkonnas on kaitsealune ohvrija ravikivi, nn Rõkandi kivi, mille kohta leidub kohapärimuse andmebaasis ligi 30 teadet, ning ka Matthias Johann Eisen on seda oma raamatus kirjeldanud (Eisen 1996: 93). Kunagi tee ääres paiknenud kivi asetseb tee nihutamise tõttu nüüd liiklejatest eemal. Ka trükisõna on paljude objektide kõnekust võimendanud ja sinna satub seetõttu ka rohkem huvilisi. Samas - kui ei ole taibatud "õigel hetkel” infot välja küsida, koos kohaandmetega kirja panna ja/või edasi rääkida, katkeb teabe levikuahel ja võimalus kaob. Nii valitsebki mõne objekti osas arhiivis vaikus ja paik kaob ka kogukonna mentaalselt kaardilt, rääkimata muudest kaartidest (vrd Tuan 1974). Täielikule vaikusele eelnes ilmselt koha tähenduse muutumine, pühapaikade puhul nende demoniseerumine (vrd Siikala 2004: 65), mille kohta ka eesti pärimuses tõendusi leiab. Alljärgnev intervjuukatkend räägib kaitsealusest Taari- ehk Taritammemäest Jüri kihelkonnas uue Tallinna-Tartu maantee ääres. Eiseni kogus on seda mainitud kui võimalikku pühakohta.

Taaritamme mägi.

Jüri kirikumõisa heinamaal on üks kaunis ilus kõrge mägi, mis "Taaritamme mägi" nimetakse. Mägi on suure Tallinna-Tartu postmaanteest üks verst maad eemal, Kautjala kruusiaugu kõrtsi karjamaa raja ääres. See maa on peaasjalikult täieste Lehmja mõisa maa; aga vana Rootsi valitsuse aegsete määruste järele on Lehmja mõis kohustatud Jüri õpetajale tükk heinamaad andma (peale selle veel köstrile karjamaa). [---] Praegust kasvavad mäel aga ainult tammevõsud, aga väga tõenäulik on see arvamine, et seal muistsel ajal vägev tammemets kasvis ja seal püha tamme puude vilus Eesti muinas Jumalat Taarat auustati ja teeniti, nagu arvatavasti nimi “Taaritamme” tähendab. (E 49077 (6) < Jüri khk - Jaan Saalverk (1914).)

Otsisime 2008. aastal paiga lähiümbrusest inimesi, kes midagigi sellest künkast rääkida oskaks, ent vaatamata pingutustele ei leidnud kedagi. Ainuke usundiline infokild paiga kohta õnnestus kuulda Tartusse kolinud kohaliku päritoluga inimeselt.

AM: Kui Tartu poolt minna, see üksik tamm ja siuke väike nukk jääb maanteest vasakut kätt, aga põhimägi jääb juba suures osas tegelikult 


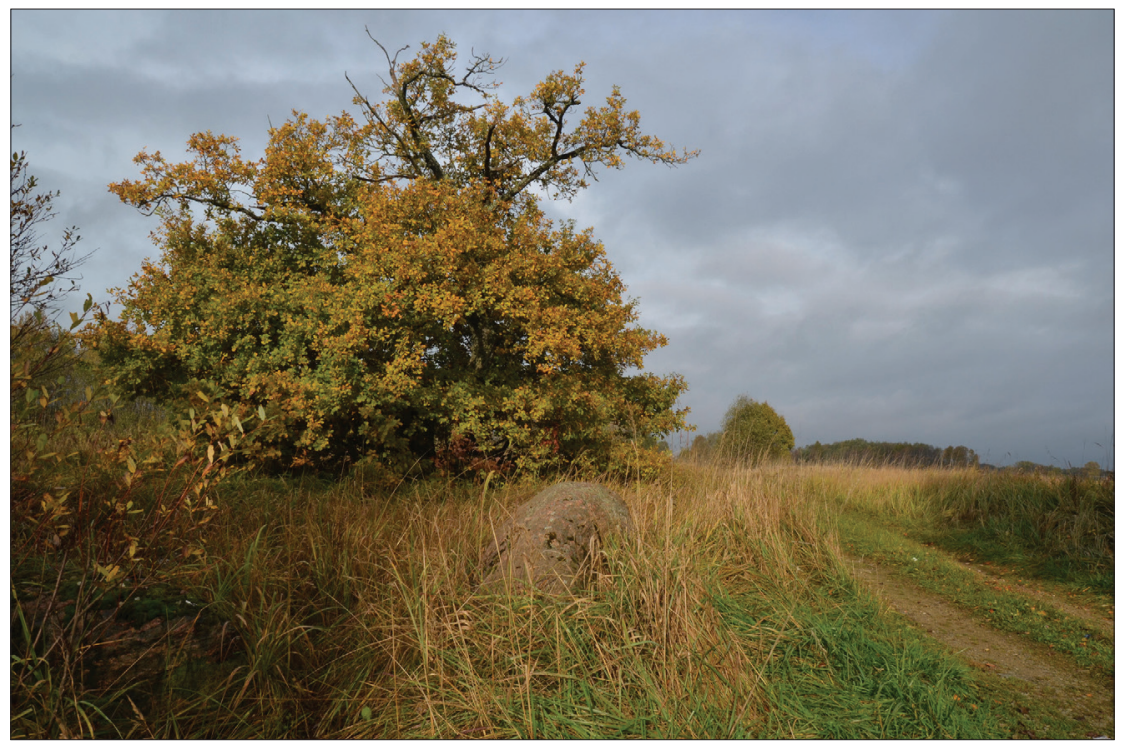

Foto 6. Taaritamme ehk Taritamme mäele viitab tänapäeval Tallinn-Tartu maantee ääres vaid üksik tamm. Mari-Ann Remmeli foto 2014.

ikkagi sinna paremale poole, need suured tammed on sealt ära ja võsa on, nii et nagu ei saagi aru, et on seal mägi on.

Aga omal ajal olid seal ka samasugused tammed ja see üksik tamm, mis teisele poole jäänud on - noh eks teda on muidugi nü̈̈d spetsiaalselt hoitud ka ikka...

Mina tean ainult seda, mis minule lapsepõlves räägiti. Minu vanaema ja vanavanaema, kes mulle ka igasuguseid lugusid rääkis, aga neid ma enam täpselt ei mäleta - kuidagi nii oli, et hobused tulid koju ja olid märjad, et hobused läksid lõhkuma seal ja sealt kardeti läbi sõita ja sealt kardeti sõita pimedal ajal ja kunagi ei teadnud siis, mis võib juhtuda. Neid täpseid legende ma nüüd enam ei mäleta, aga midagi oli.

OM: Aga hirmust selle kohaga seoses on küll, on see põgenemise ja vältimise jutt... no tema vanaema rääkis seda ju. Pühaduse ja positiivsusega seda seost küll ei olnud, ikka hirmuga.

AM: Ikka hirmuga, jah, aga vat see on kohe kindel, et seal olid mingisugused üleloomulikud vaimud. [---]

MR: Aga kas te ise ka kartsite seda kohta?

AM: Ikka, kartsin ikka! Ma lapsepõlves alati bussi aknast iga kord vaatasin seda kohta nïmoodi. Rahvas üldiselt seda rääkis, mitte päris avalikult, kõik kartsid seda - pühapäeva õhtuti oli alati nii, et kui bussid peale ei võtnud, siis kõik läksid jala sinna Sommerlingi peatusse, praeguse 
Pildiküla juurde. Sest sealt käis linnaliini buss, mis keeras Jürisse ära. Ja siis niimoodi suure seltskonnaga alati mindi, sellepärast et muidu oli sealt natuke kõhe minna. (Tartu < Jüri khk, Rae v, Patika k, Urba t Mari-Ann Remmel < Aasa Must, snd 1950; Olev Must, snd 1950 (2008), vt ka Remmel 2011: 52-53.)

\section{Lõpetuseks}

Nagu eelolevatest näidetest nähtus, pole harvad juhud, kus ühendust loo ja paiga vahel enam sõlmida ei õnnestu - kas on objekt hävinud, lähteandmed liiga napid või puudub ühendav lüli ehk infot valdav inimene. Kivi, küngas või allikas jääbki vaikselt oma olemisse, kuni heal juhul tulevad uued inimesed uusi seoseid looma. Mõnel pool on aga vana teadmine ajasõelast läbi läinud, jõuab hea õnne korral ka uurijani ning sedakaudu arhiivivarusid täiendama.

Paljud kunagised tuntud paigad, vahel ka kaitse alla võetud muistised/ objektid, on aga jäänud üksikuna keset lagedaid uudismaid või mattunud padrikusse, kuhu enam inimestel asja pole. Leidub mõistagi veel pärimusobjekte, mille juurde rajad pole rohtunud. Kas välitööuuringud, tekstipublikatsioonid ning kaardirakendused lugude, fotode ja helilõikudega suudavad vaikseks jäänud kohad taas kõnekaks muuta? Kunagisest perifeersest ja naeruvääristatud Nabalast ning teistegi pärimusraamatu saanud piirkondadest tulnud tagasiside toel võib öelda, et lootust on. Meenub ühe Nabala uusasuka hüüatus pärast raamatu lugemist: "Nüüd ma siis lõpuks tean, kus ma elan!" Kohalik territoriaalne identiteet saab jõudu pärimusest.

Tänapäeval on mitmel pool hoogsalt käimas teedevõrgu uuendused-laiendused: ringteed, asfalteeritud kergliiklusteed, müratõkkeseinad linnu ühendavatele kiirteedele, tuuleparkide rajamine, Rail Baltic, uus kõrgepingeliin - läbi maa tõmmatakse üha rohkem sirgeid jooni ja trasse, samas kavandatakse uusi kaevandusi, mis kaotaksid maa pealt hulga pärimusega vääristatud künkaid, kive, ojasid või muid maamärke.

Eks suuremaid muutusi on ka varem olnud. Ajalugu muutub üha pikemaks, kihte tuleb aina juurde ning ka paljudel nüüdseks linnadesse koondunud inimestel on alateadvuses alles esivanemate suhtumine maasse. Sestap on mõistetav ka jutustajate hirm, et maapiirkondades näevad võimud põhiliselt majanduslikku ressurssi - mets, maavarad, vesi - ning elanike isiklikku ja emotsionaalset sidet kohtadega ei võeta arvesse. Suur probleem ja korduvalt jutuks tulnud mure on veetaseme alanemine, sest paljudes kohtades on kaevud kuival. 
Selliste olukordade valguses tunduvad vanad pärimuspaigad oma lugudega kui teisest, kadunud maailmast pärit saadikud, keda sageli enam ei osata ära tunda ega väärtustada. Nende sõnumeid ei kuulda ega mõisteta. Need kohad, mis juba mingi kaitse alla ei kuulu, ning mille ümbert on inimasustus kadunud, on tõenäoliselt määratud unustusse. Nende väärtuslikkust on raske põhjendada ametnikele, seda enam, kui koha "omaniku" huvid ja väärtushinnangud on teised.

Ühiskond muutub nii kiiresti, et kindlasti tekib mõnelgi küsimus, et kas on üldse tarvis tegelda väljasurnud pärimusega? Kohapärimusega seostub järjepidevuse mõiste. On objektid, mis on "kogu aeg" olemas olnud ning pakkunud kõneainet palju inimpõlvi järjest. Muutuste tuules tahaks ju millestki kinni hoida ja mis on siis veel püsivamat kui maapind, millel elame ja liigume? Ometi on iga uus ühiskonnakord püüdnud end kehtestada ka endisaegseid maamärke kaotades ning uusi luues - nende kaudu tajume ajastute vaheldumist.

Missioon suulisest ringlusest kadunud pärimuslikku infot "reanimeerida" ja reaalsete kohtadega siduda on praeguses ühiskonnas teatud huvirühmadel siiski selgelt olemas. Tänu nende ellukutsutud projektidele, mille eesmärgiks on arhiivipärimuses mainitud maastikuobjektide kaardistamine, on justkui taas rohkem kuulda 19. ja 20. sajandi rahvaluulekogujate ja jutustajate häält, aga kas nende keelt enam mõistetakse? Mäletades vana pärimust, saaksime justkui oma maad omaks pidada ja mälestisi paremini kaitsta. Kas see ka tegelikult nii on? Näiteks looduslike pühapaikade väärtuslikkuse tõestamisel on muutunud just arhiivipärimus sageli paiga tähtsust kinnitavaks tõendiks. Kui aga on tegemist riiklike või veelgi mastaapsemate huvidega, siis ei tarvitseta pärimuse häält kuulata ja ka kõnekad kohad sunnitakse vaikima.

Käesolevas artiklis arutlesin selle üle, miks on saanud paljudest pärimuspaikadest nüüdseks vaikivad kohad ja kuidas mõnikord on vaikus sõltuvalt teabe liikumisvõimalustest suhteline. Kuni aga Eesti maapiirkondades inimasustus säilib - olgu või uusasukate näol, kuni nad jagavad eesti keeleruumi ning soovivad luua suhet ümbrusega, - jääb võimalus ka uute pärimuspaikade tekkeks, osalt ka vana pärimuse taaselustamiseks või vanadele paikadele uute tähenduste andmiseks.

\section{Tänusõnad}

Artikli valmimist on toetanud Eesti Kirjandusmuuseumi uurimisgrant EKM 8-2/20/2 (Folkloor ja selle individuaalsed, kogukondlikud ja institutsionaalsed edasiandmise mehhanismid) ja Eesti-uuringute Tippkeskus (TK 145) Euroopa Regionaalarengu Fondi kaudu. 


\section{Kommentaarid}

1 Loodusgiid Peeter Vissaku suuline teade autorile 2019.

2 EAA.1.2c.0.119.2k.

${ }^{3}$ AK Hlj: J (väljavõte: H. Kadari) (11) - väljavõte Harald Kadari poolt koostatud Haljala khk Kavastu koguk. ajaloolis-etnograafilise kirjelduse "Aegade Kavastu" käsikirjast.

4 EKIKN hlj eki1 s [170] (488297).

5 EKIKN hlj es1 i [109/13] (495695/703) - Eduard Leppik (1992).

${ }^{6}$ https://www.maavald.ee/hiis/hiied/haljala-kihelkond/1202-vihula-hiis.

\section{Allikad}

AK Hlj - Tartu Ülikooli arheoloogiakabineti arhiivi Haljala kihelkonna karp

E - Matthias Johann Eiseni rahvaluulekogu Eesti Kirjandusmuuseumis

EAA - Eesti Ajalooarhiivi (praegu Rahvusarhiiv) kaardikogu

EFA - Eesti Folklooriarhiivi rahvaluulekogu Eesti Kirjandusmuuseumis

EKIKN - Eesti Keele Instituudi kohanimekartoteek

EKLA - Eesti Kultuurilooline Arhiiv Eesti Kirjandusmuuseumis

EKRK I - Tartu Ülikooli eesti kirjanduse ja rahvaluule kateedri rahvaluulekogu

ERA II - Eesti Rahvaluule Arhiivi rahvaluulekogu Eesti Kirjandusmuuseumis

RKM II - Riikliku Kirjandusmuuseumi rahvaluuleosakonna rahvaluulekogu Eesti Kirjandusmuuseumis

\section{Kirjandus}

Bendix, Regina 1997. In search of authenticity. The Formation of Folklore Studies. Madison: The University of Wisconsin Press.

Eisen, Matthias Johann 1996. Esivanemate ohverdamised. Tallinn: Mats.

Hiiemäe, Mall 2007. Pühapaigad kui mentaalse maastiku objektid: mõiste ja väljund. Valk, Heiki (toim). Looduslikud pühapaigad: vä̈̈rtused ja kaitse. Tartu: Õpetatud Eesti Selts, lk 215-235.

Hiiemäe, Mall \& Remmel, Mari-Ann 2020. Milleks meile kohapärimus? Vahekokkuvõtteid piirialadelt. Keel ja Kirjandus 5, lk 382-400.

Jaago, Kalev \& Jaago, Tiiu 2019. Välitööd: Maidla näide. Kalmre, Eda (koost, toim). Pildi sisse minek. Artikleid välitööde alalt. Tänapäeva folkloorist 11. Tartu: EKM Teaduskirjastus, lk 87-118 (doi: 10.7592/TF11.jaagod).

Jonuks, Tõnno 2011. An archaeology of holy places; can we find "forgotten" sacred sites? Kultūras Krustpunkti 5, lk 78-88. 
Jung, Jaan 1910. Muinasajateadus eestlaste maalt III. Kohalised muinasaja kirjeldused Tallinnamaalt. Tallinn: A. Busch'i rmtkpl.

Kaasik, Ahto 2017. Pühapaikade teejuht. Eesti põlised väekohad. Tallinn: Pegasus.

Kalda, Mare 2003. Jutud peidetud varandustest. Pärimus ja meedia. Mäetagused 20 (doi: 10.7592/MT2002.20.kalda).

Kindel, Melika 2005. Vaateid kohapärimuse vä̈̈rtustamisele lähtuvalt Lahemaa turismisituatsioonist. Magistritöö. Tartu Ülikool, Eesti ja võrdleva rahvaluule õppetool (http://hdl.handle.net/10062/986 - 17. juuli 2020).

Kõivupuu, Marju 2014. Pärimus maastikul, maastik pärimuses. Hargla ja Kambja kihelkonna näitel. Kaljundi, Linda \& Sooväli-Sepping, Helen (koost \& toim). Maastik ja mälu. Pärandiloome arengujooni Eestis. Tallinn: Tallinna Ülikooli Kirjastus, lk 441-475.

McCabe, Scott \& Foster, Clare 2006. The role and function of narrative in tourist interaction. Journal of Tourism and Cultural Change, lk 1-23 (doi: 10.2167/jtcc071.0).

Mikita, Valdur 2013. Lingvistiline mets. Tallinn: Grenader.

Palang, Hannes 2014. Kokkuvõtteks. Maastiku pärandi praktikad. Kaljundi, Linda \& Sooväli-Sepping, Helen (koost \& toim). Maastik ja mälu. Pärandiloome arengujooni Eestis. Tallinn: Tallinna Ülikooli Kirjastus, lk 490-504.

Peil, Tiina 2014. Turismimaastikud ja ruumilood. Kaljundi, Linda \& Sooväli-Sepping, Helen (koost \& toim). Maastik ja mälu. Pärandiloome arengujooni Eestis. Tallinn: Tallinna Ülikooli Kirjastus, lk 399-417.

Remmel, Mari-Ann 2011. Päritud paigad. Kohajutte ja legende Rae vallast. Jüri \& Tartu: Eesti Kirjandusmuuseum.

Remmel, Mari-Ann 2017. Vennaste ja vete vald. Nabala kohajutud. Tartu. EKM Teaduskirjastus / MTÜ Sõmerlased.

Saar, Veera. 1973. Elas kord mees... Tallinn: Eesti Raamat.

Siikala, Anna-Leena 2004. Kuuluvuspaigad: ajaloo taasloomine. Mäetagused 26, lk 53-68 (doi: 10.7592/MT2004.26.siikala).

Stanton, Gareth 2020. Media, Culture and the Environmental Turn. Rowman \& Littlefield International.

Tuan, Yi-Fu 1974. Topophilia. A Study of Environmental Perception, Attitudes, and Values. Englewood Cliffs: Prentice-Hally.

\section{Summary}

\section{Silent places}

\section{Mari-Ann Remmel}

Research Fellow

Estonian Folklore Archives, Estonian Literary Museum, Estonia mariann@folklore.ee

Keywords: fieldwork, landscape, natural holy places, place lore, settlement 
The article is based on materials collected during fieldwork focusing on mapping place lore objects, including natural holy places, as well as the author's personal experience. The main focus lies on so-called silent places with scant data in the archives, and also the places difficult to identify in today's landscape without a local guide. The oldest lore narratives were written down about one and a half centuries ago. Since then landscapes have been extensively rearranged, which has brought about changes in people's way of life, their recollections of place lore narratives, and the appearance of lore places, sometimes also in their names. Northern and western Estonian hiis (holy grove) lore, for example, manifests fragmentariness and fast fading during the Soviet period. Researchers fulfilling their primary assignment within fieldwork can find themselves in rather wild conditions and therefore the romance that is perceived while reading older holy place lore tends to fade away quickly in reality.

The article emphasises that meaningful places speak, first and foremost, through people; most regions have had their own key persons with a sense of mission, thanks to whom we have archival data in the first place. The author highlights the problems of today's fieldwork, for example, difficulties in finding a well-informed guide, as consistent lore information with its carriers has often shifted away from the vicinity of the historical object and has to be searched for somewhere else. It is not seldom that links between narratives and places cannot be established anymore, as the object has been destroyed, the initial data are too scarce, or the connecting link or the person who has information is missing. So a stone, a hillock, or a spring remains silent until new people come to create new connections. On the other hand, if we interpret archival lore and old maps sensibly and competently, these silent places can sometimes be turned into eloquent ones again. But do today's people still understand what they are saying? In any case, fieldwork results can be interesting both for guides and those establishing local identity.

Mari-Ann Remmel on Eesti Kirjandusmuuseumi Eesti Rahvaluule Arhiivi teadur ja kohapärimuse töörühma juht, kes on koostanud mitu piirkondlikku väljaannet, osalenud paljudel välitöödel ning kohapärimuse andmebaasi ja kaardirakenduse loomisel. Ta on pööranud tähelepanu pärimusmotiivide regionaalsetele tagamaadele ning avaldanud ülevaateid nt kohapärimuse uurimisloost, naabrihuumorist, kogumismatkadest. Samuti on ta uurinud mõisate, kirikute, veekogude, looduslike pühapaikadega seotud pärimust.

Mari-Ann Remmel is research fellow at the Estonian Folklore Archives of the Estonian Literary Museum and head of the place lore working group. She has compiled several regional collections, participated in fieldwork and in the creation of place lore database and mapping application. Remmel has focused on the regional background of lore motifs and published overviews of local lore studies, neighbour humour, and collection expeditions. She has also studied lore related to manors, churches, water bodies, and natural holy places.

mariann@folklore.ee 